\title{
On the Benefits and Costs of Legal Expertise: Adjudication in Ancient Athens
}

\author{
Robert K. Fleck \\ John E. Walker Department of Economics \\ Clemson University \\ Clemson, SC 29634 \\ e-mail: rfleck@clemson.edu \\ F. Andrew Hanssen \\ John E. Walker Department of Economics \\ Clemson University \\ Clemson, SC 29634 \\ phone: (864) 656-5474 \\ e-mail: fhansse@clemson.edu
}

December 27, 2011

\begin{abstract}
Legal expertise permits detailed laws to be written and enforced, but individuals with expertise may employ their special knowledge to skew decisions in privately beneficial directions. We illustrate this tradeoff in a simple model, which we use to guide our analysis of the legal system in ancient Athens. Rather than accepting the costs of expertise in return for the benefits, as do most modern societies, the Athenians designed a legal system that banned professional legal experts. And this was not because Athenian society was simple: The Athenians employed sophisticated contingent contracts and litigated frequently (to the point that the law courts featured prominently in several famous comedies). Furthermore, the Athenians recognized that forgoing expertise was costly, and where the cost was particularly high, designed institutions that made use of expertise already existing in society, employed knowledgeable individuals who were unable to engage in significant rent seeking, or increased the private returns to collecting publicly beneficial information. Although the Athenian legal system differs in many ways from modern legal systems, it nonetheless functioned very effectively. Investigation of the Athenian system serves to illustrate how important it is for institutional designers to consider legal institutions as a bundle, whose pieces must complement one another.
\end{abstract}

Acknowledgments: For helpful comments, we thank two anonymous referees, Giuseppe Dari-Mattiacci, Valentina Dimitrova-Grajzl, and session participants at the 2011 meetings of the Southern Economic Association. For its generous support, Fleck thanks the Hoover Institution, where he was a 2010-11 W. Glenn Campbell and Rita Ricardo-Campbell National Fellow and the 2010-11 Arch W. Shaw National Fellow. 
An Athenian trial was entirely in the hands of amateurs. The presiding magistrate was selected by lot, the [judges] ... were drafted from the whole citizen body, any citizen could be a prosecutor, and the defendant conducted his own case.

-Bonner $(1969,60)$

In Athens, ... it is the litigants who are represented not simply as initiators but as the primary speakers and who present the court with their own (often tendentious) interpretations of the law. There is no independent judge to offer legal rulings, and the verdict is rendered by majority vote with no formal opportunity to discuss the case.

-Todd $(2005,98)$

A singular feature of the Athenian courts is the complete absence from their working of professionals or experts.

-Hansen $(1999,180)$

\section{INTRODUCTION}

In much of the modern world, the litigation process serves to inspire the collection and analysis of case-specific and issue-specific information, as well as the development of general expertise in the legal process. This in turn allows more detailed laws to be written and more sophisticated contracts to be enforced. Maskin and Tirole (2004) model the legal process and conclude that decision-making by judges is preferable to decision-making by politicians when the electorate is poorly informed about the disputed issue and acquiring decision-relevant information is costly. By contrast, when social preferences are well defined and information broadly shared, a reliance on judges rather than politicians may shift policy in socially harmful directions.

Over two millennia ago, Classical Athens - one of history's most famously democratic and commercially successful societies - eschewed legal expertise and, by doing so, greatly reduced the information-gathering role of law courts. The Athenians adjudicated through voting by randomly chosen citizens, with injured parties required to act as their own prosecuting attorneys and accused parties presenting their own defenses - forbidden by law from hiring experts to represent them. This 
was not the result of a general aversion to experts: Athenians valued and encouraged expertise in many domains, such as art, architecture, science, mathematics, and medicine. Nor was it because Athenian society was simple: Athens' economy was advanced, the demands on its legal system complex, and litigation a frequent occurrence. ${ }^{1}$ Nor was it because the Athenians were bound by an obsolete tradition: Slightly earlier in their history, Athenians had relied on a de facto independent court of last resort, which they chose to disempower as their society became more complex.

In this paper, we investigate the workings of the Athenian legal system. Our analysis takes as its focus a basic tradeoff related to expertise. The advantage of experts (over non-experts) is that experts can produce specialized information more efficiently. A disadvantage can arise, however, if experts take advantage of informational asymmetries and/or delegated powers to skew decisions in a manner that benefits the experts but not society as a whole. Modern societies accept the latter potential cost in return for the former benefit, allowing detailed laws to be written and sophisticated contracts supported. The Athenians chose differently - they designed non-professional, lowexpertise legal institutions so as to limit opportunities to amass power and/or engage in rent-seeking, and in order to elicit citizen preferences through direct participation in the litigation process. ${ }^{2}$

${ }^{1}$ Pseudo-Xenophon writes, "Here are some of the cases they [the law courts] have to decide. Someone fails to fit out a ship: judgement must be given. Another puts up a building encroaching on public land: again judgement must be given. Or to take another class of cases, adjudication has to be made between the choregi for the Dionysia, the Thargelia, and the Panathenaea year after year [a major tax on the very wealthiest citizens]. Also as between the trierarchs four hundred of whom are appointed each year, of these too, anyone who chooses must have their cases decided year after year [another major tax on the very wealthiest citizens]. But this is not all. There are various magistrates to examine and approve and decide between; there are orphans whose status must be examined . . . At intervals there are exemptions and abstentions from military service which call for adjudication, or in connection with some extraordinary misdemeanor, some case of outrage and violence of exceptional character, some charge of impiety. A whole string of others I simply omit." (Quoted in Bonner 1969, 112)

${ }^{2}$ Ober (2008) argues that most Athenian institutions - not just the legal institutions - were designed to elicit citizen preferences. 
Yet despite forgoing legal expertise, Athens managed to support a very sophisticated commercial society - and this makes the study of Athens particularly relevant to scholars interested in the relationship between legal institutions and economic performance. How were complicated contingent contracts (which Athenians employed) adjudicated by non-experts? How, without specialized prosecutors (which Athenians eschewed), could law-breaking be deterred? The Athenian answer was to design a system that made use of expertise already existing in society, relied on experts who were unable to engage in significant rent seeking, and increased private incentives to invest in publicly beneficial information. Furthermore, each piece of the Athenian legal system complemented the others, so that the system could function as a coherent whole. As a result, although Athenian legal institutions were very different from modern legal institutions, they appear to have achieved many of the same ends.

By exploring the factors that influenced the design of the Athenian legal system - and how and why they influenced it - our paper contributes to a large literature on the consequences of particular types of institutions in particular circumstances. Most closely related to our paper are studies examining the tradeoffs inherent in assigning power to a judiciary and/or politicians; e.g., Glaeser, Johnson, and Shleifer (2001), Aghion, Alesina, and Trebbi (2004), and Maskin and Tirole (2004). ${ }^{3}$ Our paper is also related to work investigating how the use of judicial power is affected by information, incentives, and shocks; see, e.g., Eskridge (1991), Ferejohn and Weingast (1992), Spiller and Gely (1992), Hanssen (1999, 2000, 2004a, 2004b), Epstein, Knight and Martin (2001), Bergara, Richman, and Spiller (2003), Epstein et al. (2005), and Fleck and Hanssen (2010,

${ }^{3}$ These papers build on a large earlier literature, including Dahl (1957, 1989), Landes and Posner (1975), and many of the studies cited in Friedman (2002). 
forthcoming). In addition, our analysis provides new insight into the workings of direct democracy (e.g., Matsusaka 1992, 2005) and the separation (or non-separation) of powers as a foundation for market economies (e.g., Weingast 1995; Qian and Weingast 1997). Finally, we contribute to the emerging law and economics literature on ancient Greece (e.g., Frier and Kehoe 2007; McCannon 2010a, 2010b, 2011).

This paper proceeds as follows. Section II describes the Athenian system of litigation. Section III develops a model to illustrate the tradeoff between using (i) relatively better informed decision-makers ("experts") who may weigh benefits and costs differently than would the representative citizen versus (ii) decision-makers who are less well informed but will weigh benefits and costs in the manner favored by the representative citizen. In Sections IV through VI, we explain how the model applies to Athenian institutions and examine the benefits and costs to the Athenians of suppressing legal expertise. Section VII concludes.

\section{THE ATHENIAN LEGAL SYSTEM DURING THE CLASSICAL PERIOD}

Our focus is on the legal system employed by ancient Athens during the Classical period, which ran from the beginning of the fifth century to the late fourth century BCE. ${ }^{4}$ It was during the Classical period that Athens reached its highest level of democracy and achieved its status as Greece's commercially most successful city-state. It was also during the Classical period that the

${ }^{4}$ Scholars typically date the Classical period from circa 480 to circa 323 BCE. Many of the legal and political institutions of the Classical period began their development during the preceding Archaic period (800-480 BCE) or the even earlier Dark Age (1150-800 BCE) that followed the destruction of the palace economies of Mycenaean civilization (1600-1150 BCE). On the nature of Athenian democracy, and in particular the informational advantages provided by a democratic system, see Ober (2008). For economic models applied to the Athenian transition to democracy, see Fleck and Hanssen $(2006,2011)$. 
institutions we describe in this paper emerged in their fullest form. ${ }^{5}$

\section{A. Litigation in Classical Athens}

Before describing Athenian legal institutions, two things regarding litigation in ancient Athens require emphasis. First, Athenian litigation often involved complicated (even by modern standards) disputes. Second, litigation was a very frequent occurrence.

To begin with, Athens was a complex society - the largest and wealthiest in ancient Greece - in which trade and specialization had advanced enormously (e.g., Morris 2010; Ober 2010). ${ }^{6}$ Several hundred thousand residents of the Attic peninsula (including 30,000-50,000 male citizens) were governed by Athenian law (Hansen 1999, 93-4), as were merchants throughout the Aegean. The Athenians were avid sea-going traders, and many complex contingent contracts were adjudicated by its maritime courts (e.g., Cohen 1973). Lending and borrowing, using real property (usually land) as collateral, was a common occurrence - Millet $(1991,5)$ marvels at "the extent to which lending and borrowing permeated Athenian society." The Athenian legal code was correspondingly

${ }^{5}$ Scholars are most knowledgeable about Athens' fourth century legal institutions; see, e.g., Hansen (1999, Chapter 2), MacDowell $(1978,8)$, and Christ $(1998,4)$ for discussions of original data sources. We should note that in focusing on the "expertise" tradeoff, we ignore other important roles played by legal institutions, such as helping promote commitment to "the rule of law." For a classic work on the emergence of the rule of law in ancient Athens, see Ostwald (1986); for an analysis from a new institutional economics perspective, see Karachalios (2011).

${ }^{6}$ Harris $(2006,145)$ writes of Classical period Athens, "Smiths made helmets, greaves, breastplates, and spears for soldiers, scythes, pruning-hooks, and ploughs for farmers, and knives for everyday use. Potters marketed a wide variety of vases for dining and symposia as well as amphoras and other jars for storage and transport. Many were engaged in making various types of clothing: there were fullers, dyers, sewers, weavers, tanners, shoemakers, and dye-makers. There were also numerous men employed in the building trades: carpenters, lead-cutters, lathe-workers, stone-cutters, sawyers, brickmakers, shipwrights, and muleteers for hauling heavy materials. And there were dozens, if not hundreds, who provided various services: doctors, barbers, hairdressers, wetnurses, innkeepers, clothes-cleaners, bankers, money-changers, bathhouse keepers, prostitutes, musicians, and various kinds of teachers. In fact, a recent study has found more than a hundred and seventy different occupations in Classical Athens. This was not a primitive economy based on subsistence agriculture." 
advanced for its time. As MacDowell $(1978,8)$ writes, "the Athenians' legal system, though less coherent than the Romans' a few centuries later, was probably the most comprehensive that any people had yet devised."

The Athenians put their legal system to prodigious use. As Bonner $(1969,96)$ writes, "[t]he litigiousness of Athenians was proverbial." Precise counts of litigated cases are impossible to obtain - systematic records have not survived (and may never have been kept) - but MacDowell $(1978,40)$ writes that "The lengthiness of the allocation procedure and the huge numbers of men included in each jury (in the fifth century as well as the fourth) show that they [the Athenians] thought it worthwhile to devote an enormous amount of time to [the law courts]." Courts, made up of several hundred to several thousand citizen-adjudicators, sat 150 to 200 days per year. ${ }^{8}$ The state spent 20 40 talents annually (a talent was equal to roughly ten-to-twenty years of income for the average skilled worker) compensating volunteer adjudicators. ${ }^{9}$ The law courts provided the playwright Aristophanes with many of his most memorable comic themes. In Clouds, a bewildered farmer views a map for the first time and objects that it could not possibly be Athens, because he can see

${ }^{7}$ See, e.g., Sealey (1987) and Hansen (1999) for detailed discussions of the development of the Athenian legal system.

${ }^{8}$ For an economic explanation of jury sizes in ancient Athens, see McCannon (2011).

${ }^{9}$ The rate of compensation was three obols per adjudicator per day (there were 36,000 obols in a talent). The payment was roughly equal to half the wage of a skilled worker in the mid-fifth century, falling to about one-quarter the wage by the late fourth century - Hansen $(1999,189)$. Roughly 1200 Athenian citizens (approximately 3 percent of the citizen body) had property in the three-to-four talent range that rendered them liable for paying for public liturgies; see Hansen $(1999,115)$. Because those who sat on the law courts were also members of the Popular Assembly, the courts were closed when the Assembly sat (Christ 1998, 20; Hansen 1999, 132-3). 
no one litigating. ${ }^{10}$

\section{B. The Law Courts}

The following quotation from Hansen $(1999,180)$ summarizes the most salient features of the Athenian legal system:

1. Judgment was not given by a professional judge but by a jury of several hundred persons. 2. The administration of the courts was in the hands of magistrates selected by lots for one year without possibility of extension. 3. There was no state prosecutor, and every charge had to be brought and carried through by an ordinary citizen acting either on his own behalf or in the public interest. 4. The parties were required to carry their suits through in person, and it was actually a punishable offense to pay someone to appear as your advocate in court.

We explore these features in detail in this sub-section.

In Classical period Athens, popular courts known as dikasteria adjudicated. Each dikasterion consisted of male Athenian citizens (all Athenian citizens were males), chosen by lot and sitting in groups numbering from hundreds to thousands depending upon the nature of the dispute. ${ }^{11}$ Any Athenian citizen over the age of thirty was eligible to sit on a dikasterion, needing only to take the law court (heliastic) oath and place his name on the roll at the start of each year; from that roll, adjudicators were chosen by lot on a daily basis. ${ }^{12}$ Some classicists refer to the men who sat on dikasteria as "jurors," while others label them "judges" - neither term being precisely correct. ${ }^{13}$ To

\footnotetext{
${ }^{10}$ Harris (2006) writes that "Aristophanes expected his audience to recognize this language and thus
} assumed that average citizens had a working knowledge of Athenian law and legal terminology."

${ }^{11}$ Women in ancient Athens had few legal or political rights (e.g., Pomeroy 1975, 2002; Blundell 1995). Fleck and Hanssen (2009) provide an economic analysis of women's rights in ancient Greece, focusing on Sparta.

${ }^{12}$ See, e.g., Hansen $(1999,89)$. In the case of a shortage of volunteers, the assembly was empowered to draft participants; in practice, this never happened as far as is known - the roles were over-subscribed.

${ }^{13}$ Christ $(1998,20)$ writes, “Although I refer to Athenian dikastai throughout this study as 'jurors', it is important to realize that they had more power than jurors in the modern United States, and performed 
avoid preconceptions, we will employ the Greek and call these citizen-adjudicators dikastai (singular dikastes).

A critical legal distinction in ancient Athens was between private (dike idia) and public (dike demosia) disputes, according whether a private individual or the state was the plaintiff. ${ }^{14}$ The injured parties exacted penalties in private disputes, while the state exacted penalties in public disputes. ${ }^{15}$ A group of about 500 dikastai would hear a typical private dispute, while as many as 1000 dikastai (or more) might be chosen to adjudicate a public dispute. Private suits could be brought only by the injured party, while public prosecutions could be brought by any citizen who wished - and the state depended heavily on "voluntary" prosecutions, because public magistrates, chosen by lot and serving non-repeatable single year terms, lacked strong incentive to bring prosecutions. ${ }^{16}$ (We will return

some tasks that are delegated to a judge in the modern context." Harris (2006, xxxi) writes, "In some of the original versions of the earlier essays, I translated the Greek term dikastai as 'juror' but have now corrected this to 'judge' throughout." Todd $(1990,19)$ writes, "we have a choice between two English equivalents, 'judges' (but with a footnote to say that in many ways the dikastai were closer to a modern jury), or else 'jurors' (again with a footnote to explain that they also performed the functions which we would associate with a judge)."

${ }^{14}$ Categories such "civil" versus "criminal" law were unknown in ancient Athens. Dike meant "judgement" or "case" rather than "justice" (as the term is most often understood today); see MacDowell $(1978,15,57)$. Separating harm done to the state from harm done to an individual was not always straightforward - the state was literally the collection of individuals (more so than in the representative democracies of today).

${ }^{15}$ Monetary fines were the most common penalty, with disenfranchisement and exile being imposed for more serious offenses. Prison terms were rare - Athens did not have long-term prisons. The exception was in maritime cases, where the guilty party was likely to flee the city; see, e.g., Bonner $(1969,94)$. Common criminals caught in the act were not tried, but rather were punished on the spot by the police magistrates and the public slaves who assisted them (Christ 1998, 20).

${ }^{16}$ MacDowell $(1978,25)$ writes that an Athenian magistrate "could not be expected to have any particular ability, knowledge, or other qualifications; he was a layman, not a specialist." Bonner $(1969, \mathrm{v})$ writes that "The law . . . permitted any man to prosecute a public offender. There were no official prosecutors." Beyond delivering a summons, a magistrate's sole responsibilities in the litigation process were to clarify the nature of the dispute and to schedule an appearance before a dikasterion. In theory, a magistrate could decide that a given dispute did not merit adjudication, but because this opened him up to 
to the topic of voluntary prosecutors in Section IV.)

Both private and public litigation began with a summons to the accused party, requiring him to present himself before the appropriate magistrate on a given day. In private cases, it was the responsibility of the injured citizen to deliver the summons; in public cases, the summons could be delivered either by a magistrate or by the voluntary prosecutor.

A trial lasted one day at most. ${ }^{17}$ The litigating parties were responsible for obtaining copies of the relevant laws before the trial convened, and taking them to the court where they would be read aloud by a clerk at the start of the trial. The plaintiff and defendant would then lay their cases before the dikastai, each party speaking for himself. ${ }^{18}$ Speeches were limited to a fixed amount of time, as measured by a water clock. Witness testimony could be introduced (originally, in person, later, in written form), and a litigant's speaking time (15 minutes or so) could be shared with a friend however, paying another to serve as one's advocate was forbidden by law (e.g., MacDowell 1978,

a lawsuit, it was rare for him to do so (Bonner 1969, 48). There were between 700 and 1100 magistrates holding office in Athens at any given time, carrying out functions ranging from supervising the cleaning of the streets to supervising the markets to supervising the law courts to organizing festivals (Christ 1998, 18; Hansen 1999, 230). All magistrates were subject to review (dokimasia) before taking office and audit (euthunai) afterwards (e.g., Christ 1998, 18). Most magistracies had a minimum age requirement of thirty (similar to the courts), and for some offices the minimum age may have been 40 (see Hansen 1999, 89).

${ }^{17}$ Todd $(2005,110)$ writes, "Athenian justice was rapid: so far as we know, dicastic trials never overran the day, and many private cases were considerably shorter than this." The length of time that would pass between a formal charge and a trial is less certain. See also Bonner (1969), MacDowell (1978, 247-54), and Christ (1998, 14-47) for detail on what follows in this section.

${ }^{18}$ It was considered marginally acceptable to have a speech written by a professional speech writer, but the citizen, himself, had to recite it (and even then, he would make it clear that the speech writer had merely helped put the litigant's own thoughts in words). Hansen $(1999,194)$ writes that "logography [speech writing] was regarded with skepticism and suspicion, and the profession had little standing: several Athenian political leaders, Demosthenes and Hyperiedes for example, began as logographers, but gave it up as fast as they could and did not like to be reminded of that stage in their careers." Todd $(2005,102)$ writes, "Logography ... was clearly a professional business, although we know virtually nothing about the level of fees it commanded. As befits its nonformal status, it had something of a shady reputation, at least in certain circles." 
251; Hansen 1999, 194). Cross-examination was not allowed, although the litigants were permitted to make speeches in rebuttal if time remained to them, and questions shouted by individual dikastai may have been answered on occasion. ${ }^{19}$ The wives and children of the litigating parties were sometimes introduced - their presence was believed to elicit the sympathy of the dikastai. This mattered, because the dikastai were essentially unconstrained in how they decided a case. There was no requirement that the decision respect precedent, or even follow a particular understanding of the law. ${ }^{20}$ The only requirement was that it earn a majority of votes among the dikastai.

On the conclusion of the case, the dikastai voted secretly, without deliberation - Hansen $(1999,202)$ writes, "it was thought undesirable for them to exchange even a word or two about the case." If the verdict went against the plaintiff, the case was dismissed. If instead the defendant was found guilty, punishment had to be determined. In public cases, statutorily established penalties might be employed, while in some private disputes (e.g., breach of contract), the penalty specified by the plaintiff in the course of the trial was enforced. If no penalty was specified, a second trial was held immediately after the first, with plaintiff and litigant each proposing and arguing for particular penalties. ${ }^{21}$ No input from the dikastai was allowed, nor could the dikastai choose to impose an

${ }^{19}$ Todd $(2005,109)$ writes, "One of the strongest impressions created by our texts is that Athenian litigation took the form of continuous though relatively short speeches, rather than the cut and thrust of extended cross-examination and debate that is the pattern of modern Anglo-American jury trials." Todd notes that litigants may have had the power to insist that direct questions be answered - the evidence is not clear.

${ }^{20}$ Bonner (1969, v, 104) writes, "Thus, the people actually administered justice, interpreting and applying the law in each case as they saw fit. No trained jurist on the bench balked the popular will by citing inconvenient precedents. In theory, a judicial decision rendered today could be reversed in a similar case tomorrow" and "in Athens the decisions of one court did not bind another. Each jury interpreted and applied the law as it saw fit."

${ }^{21}$ Alternatively, plaintiff and defendant could agree by themselves on a penalty (Lanni 2005, 119). 
alternate penalty. Upon conclusion of the arguments, the dikastai would again vote, and the penalty that received the most votes was applied..$^{22}$

There was no appeal. A dikasterion was a fully constituted representative of the state, and its decisions were binding. As MacDowell $(1978,40)$ writes,

An Athenian jury was the people. When a speaker addressing a jury wishes to refer to the Athenian state, his word for it is the pronoun 'you.' And since in democratic Athens the people was supreme, a decision by a jury was final. There could be no appeal. $^{23}$

\section{THE MODEL}

The purpose of the model is to illustrate a key tradeoff that must be faced when establishing a legal system. Consider a society that 1) wants courts to make the decisions that a perfectly well informed representative citizen would make, but 2) is constrained by the fact that no one is perfectly well informed. Moreover, the better informed individuals may or may not be representative of the citizenry as a whole. How will this society design its legal system? To address that question, we develop the following model.

\section{A. Assumptions}

(A1) Representative Court Case. From the perspective of a perfectly informed representative citizen, the net value (i.e., benefits minus costs) of deciding "yes" (rather than "no") in a court case is $y$, where $y=b-c$. Let $b$ randomly take one of two values $(0$ or $\beta)$, with $\beta>0$ and

${ }^{22}$ See, e.g., MacDowell $(1978,253)$. Recall the famous trial of Socrates. Following the dikastai verdict of guilty, the prosecution demanded death. Rather than proposing a lesser penalty, such as a fine or exile, which would have been typical for a guilty party, Socrates argued that his actions had benefitted society and that he should be given a life stipend instead. Faced with these alternatives, the dikastai voted to execute Socrates. For an analysis of the trial based on a formal model, see McCannon (2010b).

${ }^{23} \mathrm{~A}$ new trial was allowed if a witness was found guilty of perjury (Bonner 1969, 56). 
$P(b=0)=P(b=\beta)=.5$. Let $c=.5 \beta .^{24}$

(A2) Lower Expertise Group. Everyone in this group observes $b_{\mathrm{L}}$ rather than $\mathrm{b}$, with $\mu_{\mathrm{L}}$ the probability that $\mathrm{b}_{\mathrm{L}}$ is a mistake; $0<\mu_{\mathrm{L}}<.5$. That is: $\mathrm{P}\left(\mathrm{b}_{\mathrm{L}}=0 \mid \mathrm{b}=\beta\right)=\mathrm{P}\left(\mathrm{b}_{\mathrm{L}}=\beta \mid \mathrm{b}=0\right)=\mu_{\mathrm{L}}$; $\mathrm{P}\left(\mathrm{b}_{\mathrm{L}}=0 \mid \mathrm{b}=0\right)=\mathrm{P}\left(\mathrm{b}_{\mathrm{L}}=\beta \mid \mathrm{b}=\beta\right)=1-\mu_{\mathrm{L}}$.

(A3) Higher Expertise Group. Everyone in this group observes $b_{\mathrm{H}}$ rather than $\mathrm{b}$, with the probability of a mistake below that for the lower expertise group: $0<\mu_{\mathrm{H}}<\mu_{\mathrm{L}}<.5 ; \mathrm{P}\left(\mathrm{b}_{\mathrm{H}}=0 \mid \mathrm{b}=\beta\right)$ $=\mathrm{P}\left(\mathrm{b}_{\mathrm{H}}=\beta \mid \mathrm{b}=0\right)=\mu_{\mathrm{H}} ; \mathrm{P}\left(\mathrm{b}_{\mathrm{H}}=0 \mid \mathrm{b}=0\right)=\mathrm{P}\left(\mathrm{b}_{\mathrm{H}}=\beta \mid \mathrm{b}=\beta\right)=1-\mu_{\mathrm{H}}$.

(A4) Decision by a Jury. The court case will be decided ("yes" or "no") by a jury drawn either from the lower expertise group or from the higher expertise group. With $\mathrm{i}$ indexing the type of jury ( $\mathrm{L}$ or $\mathrm{H}$ ), let $\rho$ be the probability that $\mathrm{y}_{\mathrm{i}}>0$ leads to a "yes" decision and $\mathrm{y}_{\mathrm{i}}<0$ leads to a "no" decision:

$$
\mathrm{P}\left(\text { yes } \mid \mathrm{y}_{\mathrm{L}}>0\right)=\mathrm{P}\left(\text { yes } \mid \mathrm{y}_{\mathrm{H}}>0\right)=\mathrm{P}\left(\text { no }_{\mathrm{L}}<0\right)=\mathrm{P}\left(\text { no } \mid \mathrm{y}_{\mathrm{H}}<0\right)=\rho
$$

with $y_{L}=b_{L}-c ; y_{H}=b_{H}-c d ; .5<\rho<1$. Here, $d \neq 1$ indicates the higher expertise group's deviation from the way in which the representative voter evaluates costs. Let $d$ take one of three different values: $\mathrm{d}=0$ with probability $.5 \delta ; \mathrm{d}=2$ with probability $.5 \delta ; \mathrm{d}=1$ with probability $(1-\delta) ; 0<\delta<1$. Random draws of $d$ are independent of other factors (notably mistakes made when observing signals of $b$ ) and observable only by higher expertise jurors. The parameter $\rho$ accounts for factors that influence mistakes in a manner unrelated to the level of expertise.

\section{B. Implications}

From the representative citizen's perspective, which type of jury will yield the higher expected payoff? Note that the following results hold, ceteris paribus. First, the greater the propensity for members of the lower expertise group to make a mistake when observing a signal of benefits (i.e., the greater $\mu_{\mathrm{L}}$ ), the lower the payoff from a lower expertise jury. Second, the greater the propensity for members of the higher expertise group to make a mistake when observing a signal

${ }^{24}$ By employing the assumption that $\mathrm{c}=.5 \beta$, combined with the assumption that $\mathrm{b}$ randomly takes values of 0 or $\beta$, we characterize a representative court case in which random decision-making would have zero expected net benefits. This makes it straightforward for us to model the type of divergence in preferences in which we are interested: The general public knows that, on any given case, a higher expertise subset of the population may have non-representative preferences, but the general public does not know the direction of the divergence. 
of benefits (i.e., the greater $\mu_{\mathrm{H}}$ ), the lower the payoff from a higher expertise jury. Third, the more likely it is that the higher expertise group will weigh costs (relative to benefits) in a manner different from what the representative citizen would want (i.e., the higher $\delta$ ), the lower the payoff from a higher expertise jury. ${ }^{25}$ Moreover, from these ceteris paribus effects, it follows that a sufficient change in the expertise gap (i.e., a sufficient change in $\mu_{\mathrm{L}}-\mu_{\mathrm{H}}$ ) or a sufficient change in the frequency with which there occurs a divergence in the weights placed on costs (i.e., a sufficient change in $\delta$ ) will swing the preferred type of jury between the two choices. ${ }^{26}$ Finally, note that a higher value of $\rho$ (i.e., a reduced overall propensity for mistakes) is valuable.

\section{Tradeoffs Involving the Values of $\delta$ and $\mu$}

We will now examine a different type of tradeoff related to $\delta$ and $\mu$. Recall that our model has, so far, treated $\delta$ and $\mu$ as exogenous parameters. This serves well for modeling a discrete higher-expertise versus lower-expertise decision. An additional point to consider, however, is that (regardless of which option is chosen) the public would benefit if $\delta$ and/or $\mu$ were reduced. This matters for applying the model, because an effective legal system will include features designed to reduce the frequency of events that cause undesirable outcomes. For this reason, we will now

${ }^{25}$ To obtain these results, let $\mathrm{EV}_{\mathrm{L}}$ and $\mathrm{EV}_{\mathrm{H}}$ denote the expected value of the decisions made by each type of jury. Based on the model's assumptions, the expected values can be expressed as follows:

$$
\begin{aligned}
& \mathrm{EV}_{\mathrm{L}}=(.5) \mathrm{P}(\text { yes } \mid \mathrm{b}=\beta) \mathrm{P}(\mathrm{b}=\beta)-(.5) \mathrm{P}(\text { yes } \mid \mathrm{b}=0) \mathrm{P}(\mathrm{b}=0)=(.25)\left[2 \rho-4 \mu_{\mathrm{L}} \rho+2 \mu_{\mathrm{L}}-1\right] \\
& \mathrm{EV}_{\mathrm{H}}=(.5) \mathrm{P}(\text { yes } \mid \mathrm{b}=\beta) \mathrm{P}(\mathrm{b}=\beta)-(.5) \mathrm{P}(\text { yes } \mid \mathrm{b}=0) \mathrm{P}(\mathrm{b}=0)=(1-\delta)(.25)\left[2 \rho-4 \mu_{\mathrm{H}} \rho+2 \mu_{\mathrm{H}}-1\right]
\end{aligned}
$$

Given the parameter restrictions $\left(0<\mu_{\mathrm{L}}<.5 ; 0<\mu_{\mathrm{H}}<.5 ; .5<\rho<1\right)$, it must be that the results stated in the text hold: $\partial \mathrm{EV}_{\mathrm{L}} / \partial \mu_{\mathrm{L}}<0 ; \partial \mathrm{EV}_{\mathrm{H}} / \partial \mu_{\mathrm{H}}<0 ; \partial \mathrm{EV}_{\mathrm{H}} / \partial \delta<0$. It also follows that: $\mathrm{EV}_{\mathrm{L}}>0 ; \mathrm{EV}_{\mathrm{H}}>0 ; \partial \mathrm{EV}_{\mathrm{L}} / \partial \rho>0 ; \partial \mathrm{EV}_{\mathrm{H}} / \partial \rho>0$.

${ }^{26}$ To see why, note the following. For sufficiently high values of $\mu_{\mathrm{L}}$ (e.g., consider $\mu_{\mathrm{L}} \rightarrow .5$ ), ceteris paribus, a higher expertise jury will be preferred $\left(\mathrm{EV}_{\mathrm{L}}<\mathrm{EV}_{\mathrm{H}}\right)$, while for sufficiently low values (e.g., consider $\left.\mu_{\mathrm{L}} \rightarrow \mu_{\mathrm{H}}\right)$, a lower expertise jury will be preferred $\left(\mathrm{EV}_{\mathrm{L}}>\mathrm{EV} \mathrm{H}_{\mathrm{H}}\right)$. For sufficiently high values of $\mu_{\mathrm{H}}(\mathrm{e}$.g., consider $\mu_{\mathrm{H}} \rightarrow \mu_{\mathrm{L}}$ ), a lower expertise jury will be preferred. A value of $\delta$ sufficiently close to one will, ceteris paribus, guarantee $\mathrm{EV}_{\mathrm{L}}>\mathrm{EV}_{\mathrm{H}}$, while a value of $\delta$ sufficiently close to zero will, ceteris paribus, guarantee $\mathrm{EV}_{\mathrm{L}}<\mathrm{EV}_{\mathrm{H}}$. 
modify the model so that the values of $\delta$ and $\mu$ depend on a policy decision.

Consider a choice of whether to take an action that has $\operatorname{cost} \kappa$ (with $\kappa \geq 0)$, where $\alpha=1$ denotes taking the action ( $\alpha=0$ otherwise). To ensure that the decision involves a tradeoff, assume there is at least one benefit (i.e., $\delta$ and/or $\mu$ decrease) and at least one cost (i.e., $\kappa>0, \delta$ increases, and/or $\mu$ increases). ${ }^{27}$ Putting this in terms of parameters, let: $\delta=\delta_{0}+\alpha \delta_{\alpha} ; \mu=\mu_{0}+\alpha \mu_{\alpha \cdot}{ }^{28}$ Based on these assumptions, the expected net value of taking the action is:

$$
\mathrm{EV}_{\alpha}=(.25)\left(1-\delta_{0}-\delta_{\alpha}\right)[2 \rho-1]\left[1-\mu_{0}-\mu_{\alpha}\right]-\kappa-(.25)\left(1-\delta_{0}\right)[2 \rho-1]\left[1-\mu_{0}\right]
$$

By examining the conditions under which $\mathrm{EV}_{\alpha}>0$, we can identify the conditions under which the policy in question (i.e., setting $\alpha=1$ ) will, in expectation, be beneficial. With better expected court decisions on both dimensions $\left(\delta_{\alpha}<0\right.$ and $\left.\mu_{\alpha}<0\right)$, then a sufficiently low cost (low $\left.\kappa\right)$ will guarantee that the policy will have positive expected benefits. Yet if the policy has mixed effects on the accuracy of the decision (i.e., $\delta_{\alpha}$ and $\mu_{\alpha}$ have opposite signs), there will be a tradeoff in terms of the effects on court decisions (and perhaps also with cost $\kappa$ ). More specifically, with $\delta_{\alpha}<0$ and $\mu_{\alpha}>0$, the policy will have positive expected benefits if $\mu_{\alpha}$ is sufficiently low (given $\kappa$ sufficiently low for $\mathrm{EV}_{\alpha}>0$ to be feasible). Similarly, with $\delta_{\alpha}>0$ and $\mu_{\alpha}<0$, the policy will have positive expected benefits if $\delta_{\alpha}$ is sufficiently low (given $\kappa$ sufficiently low for $\mathrm{EV}_{\alpha}>0$ to be feasible).

\footnotetext{
${ }^{27}$ If a costless policy (i.e., $\kappa=0$ ) would reduce $\delta$ and/or $\mu$ without increasing either $\delta$ or $\mu$, the policy would obviously be desirable; thus, we focus on the more interesting cases, in which there is a tradeoff.

${ }^{28}$ Restating more formally the assumptions that guarantee a tradeoff: There is at least some benefit of setting $\alpha=1$ (i.e., $\delta_{\alpha}<0$ and/or $\mu_{\alpha}<0$ ), and at least some opportunity cost of setting $\alpha=1$ (i.e., if $\delta_{\alpha} \leq 0$ and $\mu_{\alpha} \leq 0$, then $\kappa>0$ ). To keep $\delta$ and $\mu$ within the bounds stated earlier, it must also be that $0<\delta_{0}+\alpha \delta_{\alpha}<1$ and $0<\mu_{0}+\alpha \mu_{\alpha}<.5$, for $\alpha=1$ and for $\alpha=0$.
} 


\section{FORGOING LEGAL EXPERTISE}

In what follows, we apply the model to ancient Athens. We will consider why the Athenians chose to forgo the advantages of professional expertise and how they mitigated some of the undesirable consequences of that choice.

As a starting point, consider the plausibility of our model as way to explain the design of Athenian legal institutions. Recall from the discussion in Section II that the Athenian system's key features (adjudication by randomly chosen citizens, prohibition against paid legal representation, and so forth) are akin to the "lower expertise" approach characterized in our model. ${ }^{29}$ If the basic tradeoff at the core of our model has practical value for understanding institutional design in Athens, then the Athenians must have sought to avoid circumstances under which coalitions or individuals could sway collective decisions away from what the general public desired. This was indeed the case.

One reason is that a history of factional conflict had made Athenians extremely wary of concentrating power in any but the most broadly representative of the public bodies. As Morris $(2005,20)$ explains, in Athens "classical democracy was a kind of compromise between the need to have state institutions and the desire to prevent anyone from capturing them." Adjudication via large numbers of randomly chosen citizens made both direct and indirect (through the buying of influence)

\footnotetext{
${ }^{29}$ Even a highly educated dikastes cast only one vote among hundreds (or thousands), so that his incentive to become informed about a given issue - or the law in general - was very weak. And even individuals who intended to serve repeatedly as dikastai would likely find themselves assigned to very different cases each time they were selected. Furthermore, the requirement that plaintiffs and litigants present their own cases prevented a coterie of professional litigators from emerging. Bonner $(1969, \mathrm{v})$ writes, "Athenians tried to prevent the rise and development of a legal profession. The law required every man to plead his own case in court." As noted in an earlier footnote, professional speech writers could be employed, although they had "shady" reputations.
} 
concentrations of power nearly impossible - the number of men to organize or pay off was potentially enormous, and the random assignment of men to panels and panels to cases would have hobbled attempts to track compliance with bribe-induced obligations. ${ }^{30}$ Making legal decisions in this manner was costly, both because the lack of expertise would lead to more mistakes when evaluating information (higher $\mu$ ) and because it required the time of so many citizens (substantial $\kappa)$. But by incurring those costs, the Athenians obtained a highly representative (low $\delta$ ) decisionmaking system.

For some perspective on how this fits into a broader picture of Athenian society, it is important to recognize that Athenian institutions as a whole (not just the legal system) were designed to elicit the preferences of the citizenry in a quite direct fashion. As Ober $(2006 \mathrm{a}, 14)$ explains, "Athenian democracy had a distinctive design principle: it was designed for organizing the dispersed knowledge of citizens." Of course, the dikasteria did not mirror the citizenry precisely (notably, citizens sat in the Assembly from age twenty, while dikastai were drawn solely from the citizen

\footnotetext{
${ }^{30}$ Athenian concern with bribery, spurred by several fifth century scandals, led to a major reengineering of the dikastes-selection procedure (see, e.g., MacDowell 1978, 40; Hansen 1999, 197). The Athenians had originally allocated dikastai to panels at the start of each year, and panels to cases at regular intervals. After the bribery scandals, Athenians began instead to allocate both on a daily basis. Throughout the fourth century, an amazingly complex system - involving intricate machinery consisting of a frame with variety of tubes and exit holes into which were placed black and white balls - allocated dikastai to panels, panels to cases, and supervising magistrates to cases. The same system was used to determine the individual dikastai responsible for controlling the water clock (one dikastes), counting the votes (four dikastai), and paying the dikastai when the day's business was over (five dikastai). See Hansen (1999, 198-9) for a more detailed description of the procedure. Hansen $(1999,199)$ writes, "No one has ever calculated how long this procedure took," but his best guess is that 2000 citizens spent at least an hour a day at it on each of the roughly 200 litigating days per year. The Constitution of Athens devotes four whole chapters to describing the process by which dikastai are allocated. In addition, there were substantial fines for bribery - briber and bribed were assessed ten times the amount of the original bribe, plus were disenfranchised, along with their descendants, until the fines were paid (MacDowell 1978, 172).
} 
population over the age of thirty). ${ }^{31}$ Nonetheless, argues Ober (2006b, 226), each judgement by a dikasterion

was a public expression of the preferences of an informed subset of the citizenry. . . The jury's vote was at once a product of aggregating the latent and newly learned knowledge of the individual jurors and a product of partial coordination among jurors based on their ex ante and ex post common knowledge.

This is not to say, however, that the Athenian judicial system was merely an additional legislative branch. Recall that dikasteria restricted the quantity and style of oratory, and deliberation among dikastai was nonexistent. Moreover, while debate in the Popular Assembly (Athens' principal governing body, on which all citizens sat) was intended to coalesce mass support for (or opposition to) specific policies proposed by Athenian statesmen, dikasteria were expected "to judge fairly on the available evidence in an attempt to secure justice" (Ober 2006b, 223). ${ }^{32}$

\section{A. Law without Professionals}

The absence of professionals - namely judges and lawyers - placed a constraint on the nature of the law. Had there been a complex written legal code, it would have been impossible for randomly chosen dikastai to "judge fairly" and "secure justice" (borrowing Ober's words), especially

\footnotetext{
${ }^{31}$ An Athenian male came of age at age eighteen, but from the late 370 s eighteen- and nineteen-year old Athenian males participated in mandatory military service, which meant they would not have started sitting in the Assembly until age twenty; see Hansen $(1999,89)$. Hansen $(1999,181)$ estimates that only about two-thirds of the adult male citizen population would have been eligible for service as dikastai. Of course, this is not to say that dikastai were perfectly representative of the population over thirty. Some scholars have suggested that the elderly and the poor (with lower opportunity costs) were more eager to serve as paid dikastai; other scholars have disagreed. See, e.g., MacDowell $(1978,35)$.

${ }^{32}$ Athens was a direct democracy, with no political parties and no elected politicians. Individual Athenians could nonetheless rise to positions of political prominence - become "statesmen" - by taking active roles in policy debates, either making policy proposals or arguing against them. Christ $(1998,19)$ writes, "important as leaders and advisors were orators, who, although they held no official position, gained public prominence and political power by regularly addressing the Assembly and bringing [political] suits before the courts."
} 
with the accustomed rapidity (trials of one day or less). Thus, the Athenian system of adjudication by non-experts was supported by a heavy emphasis on social norms. The Athenians considered themselves a people governed by fundamental rules - nomoi (singular nomos) - which they distinguished from the Assembly's legislative acts (known as psephisma, or “decrees"). ${ }^{33}$ Although many nomo $i$ were written down, particularly following a late fifth century law code revision (Hansen 1999), the word nomos means "custom" or "way of doing things." As MacDowell $(1978,44)$ explains, "it is the term for a norm of action recognized by society, what is agreed to be the right thing to do." Would-be dikastai swore an oath at the start of each year that is believed to have included the words, "I will judge according to the laws and decrees of Athens, and matters about which there are no laws I will decide by the justest opinion" (MacDowell 1978, 44, italics added). Dikastai were not expert in the written law, nor were they instructed by experts in the written law, but they were the "experts" (in a sense) in Athenian norms - these flowed from them and were embodied in their decisions. ${ }^{34}$ Indeed, there was widespread belief that Solon - the famous lawgiver who produced Athens' most revered written code - had made laws indeterminate on purpose in order to increase the discretion of citizen-adjudicators (Bonner 1969, 104). ${ }^{35}$ (This may help explain why,

${ }^{33}$ Decrees tended to be temporary or specific in kind (e.g., the granting of citizenship to a particular foreign resident), while nomoi were fundamental and permanent. That said, litigants did not necessarily distinguish carefully between the two. See the discussion in MacDowell (1978, 43-6).

${ }^{34}$ This is consistent with the lack of regulation (social and economic) that characterized ancient Athens. As Hansen $(1999,80)$ writes, "the public sphere (i.e. the polis sphere) was specifically a political sphere: the polis did not regulate all matters but only a limited range of social activities, and matters such as education, industry, agriculture and trade were left to private enterprise. But, further, Athenians were regularly allowed to think and say what they liked about anything, as long as they did not, for example, profane the Mysteries, or, without due permission, form new cults and religious societies."

${ }^{35}$ Some scholars have proposed that the Athenians had a simple code of laws because they failed to grasp the complex requirements of rigorous adjudication - their primary evidence being that Athenians tended not to define precisely the wrongdoing for which they stipulated penalties. For example, the Athenian 
as discussed earlier, the ruling of a dikasterion did not need to follow precedent and was not subject to appeal.)

Norms cannot, however, provide a complete substitute for a precise legal code. Consequently, the Athenian approach had less than universal support among the residents of Athens. Plato, for example, was very critical of the leeway granted to dikasteria, arguing that if such citizenmanned courts were to exist at all, they should be sharply constrained by precisely written laws crafted by “experts" (Christ 1998, 24). ${ }^{36}$ Aristotle basically agreed, but also pointed out an important tradeoff closely related to the theme of this paper: Corrupting "the many" is much more difficult than corrupting "the few" (Pol. 1286a35-40). To put this in the context of our model, the reliance on norms may have been optimal given that Athens chose a lower-expertise legal system; that is, it allowed a relatively low $\mu$ without the higher $\delta$ necessary to obtain an even lower $\mu$.

\title{
B. Prosecuting Public Offenses without Professionals
}

Forgoing legal experts, Athens had little choice but to rely on volunteer prosecutors to bring

\begin{abstract}
law against hubris explains how violators may be prosecuted, but does not specify precisely what hubris is, or what actions should constitute punishable hubris (e.g., Carey 1998). However, classicists have increasingly argued that Athenians shared an understanding of the nature of illegal acts that rendered precise definitions unnecessary (Harris 2006, Ch. I.3; Lanni 2005). Lannie $(2005,113)$ writes, "I argue that the nonlegal arguments we meet in the surviving [law court] speeches were vital components of making a case in an Athenian popular court rather than aberrations in an essentially modern legal system. However, the seemingly irrelevant material does not suggest a disregard for the factual and legal issues in dispute in favor of an unrelated social purpose; rather extra-legal arguments provided information about the context of the dispute to assist the popular court jury in reaching a just verdict that took into account the particular circumstances of the individual case." This view is also reflected by Todd and Millet $(1990,14)$, who write, "Athenian courts were more concerned with dispute-settlement than with the enactment of justice in our objective sense."

${ }^{36}$ In Republic, Plato writes, "a shoemaker shall be a shoemaker and not a pilot also, and a farmer shall be a farmer and not a dicast also." However, in Laws, Plato appears to concede some value to popular courts, writing that "In the judgement of offenses against the state the people ought to participate, for when anyone wrongs the state they are all wronged." Both quotations are from Bonner $(1969,88)$.
\end{abstract}


charges for public offenses. ${ }^{37}$ This presented the Athenians with a challenge: to design a system that would 1) encourage an action for which the direct benefits to the actor were otherwise very small, while 2) ensuring that the encouragement did not produce a situation in which there were too many prosecutions. These were conflicting objectives and thus forced the Athenians to face a tradeoff when designing their legal system.

Early on, efforts to inspire private citizens to bring public suits focused on exhortation. For example, Solon, who is credited with establishing the system of volunteer prosecutors (so that "volunteers avenge the wronged") declared that it ought to be every citizen's responsibility to ensure that the laws are obeyed and people behave properly:

the best-governed state is that in which those who are not wronged are no less diligent in prosecuting wrongdoers than those who have personally suffered. Citizens like members of the same body should feel and resent one another's injuries. (Bonner 1969)

In practice, exhortation alone would have provided only a weak inducement for volunteers to incur the costs of prosecuting the guilty. Thus, many wrongdoers would have gone unprosecuted and, hence, unpunished. In the context of the model, this corresponds to a large $\mu .{ }^{38}$

It is, of course, quite straightforward to strengthen incentives for volunteers to bring

${ }^{37}$ MacDowell $(1978,62)$ writes, "it would not be true to say that publicly appointed prosecutors did not exist in Athens. Nevertheless, most public cases were brought by volunteers." For example, although some Athenian magistrates had ostensible responsibility for particular public offenses (such as the ten synegoroi charged with prosecuting cases against former officeholders), these magistrates were (like all magistrates) chosen by lot, served for only a single year, and could not hold the same position twice (MacDowell 1978, 61). In both expertise and incentives to prosecute, therefore, they differed little from the average citizen. This contrasts starkly with modern societies, where career concerns (among other things) typically provide public prosecutors with the incentive to pursue wrongdoers (e.g., Glaeser, Kessler, and Piehl 2000; Stuntz 2001; Rasmusen, Rhagav and Ramseyer 2009; Bandyopadhyay and McCannon, 2010a).

${ }^{38}$ More specifically, while the cost $(\kappa)$ of exhortation was presumably low, so were the benefits (i.e., $\mu_{\alpha}$ was negative but of small magnitude). 
prosecutions - the key issue is whether an action will yield benefits (i.e., reduced $\mu$ ) are worth the costs (i.e., $\kappa$ and/or increased $\delta$ ). By the fifth century, Athens was employing a system under which citizens who brought successful prosecutions received a portion of the amount collected from the offender. Volunteers who brought a type of prosecution known as phasis - employed most often for market offenses, such as using inaccurate weights, selling goods imported from an enemy state, or refusing to accept coins verified as genuine by a state coin-tester (MacDowell 1978, 158)-collected half the assessed fine. Volunteers who brought a type of prosecution known as apographe - a means of confiscating property from those owing debts to the state, for things such as taxes or payments on mining leases (MacDowell 1978, 62) - received three-quarters of the amount the state recovered. There were a number of other types of prosecutions for which voluntary prosecutors received financial rewards. ${ }^{39}$ Such rewards helped align private interests with social interests, and inspired public prosecutions in the absence of specialized prosecutors.

This brings us back to the fundamental tradeoff illustrated in our model. Under an Athenianstyle compensation system, volunteer prosecutors have the incentive to acquire and reveal information from which the general citizenry can (at least in principle) benefit. Yet the presence of compensation will also create an incentive to bring forward cases that the general citizenry, if well informed, would not want brought forward. Without question, this was a serious problem for Athens. Contemporary complaints about the Athenian legal system focused on sykophantes, or

\footnotetext{
${ }^{39}$ For example, if an alien man was found guilty of cohabiting with a Athenian female, or of giving an alien woman in marriage to an Athenian citizen, his property was confiscated and one-third of it was given to the voluntary prosecutor - see MacDowell $(1978,62)$.
} 
"sycophants" - men who prosecuted innocent parties in order to extract payments. ${ }^{40}$ According to Demosthenes, a sycophant "makes all kinds of charges and proves none" (quoted in Bonner 1969, 64). Sycophants were pervasive enough to play prominent roles in several of Aristophanes' comedies - most memorably in Akharnians, where a Boiotian visitor looking for a characteristically Athenian product has a sycophant wrapped up to take home with him.

The Athenians established several policies intended to reduce sycophancy. First, they instituted punishments - ranging from monetary fines to a prohibition on bringing additional prosecutions to full disenfranchisement - for voluntary prosecutors who received less than one-fifth of the dikastai votes, or dropped prosecutions before completion (MacDowell 1978, 64; Christ 1998, 28-9). In addition, many public suits required deposits to be paid in advance (the proceeds from public suits were shared with the state) - these were forfeit if the case was lost. ${ }^{41}$ Futhermore, citizens who believed themselves targeted by a sycophant could bring counter-suits charging prosecution without justification (this was used most frequently in maritime disputes). ${ }^{42}$ Finally, a man could be charged directly with sycophancy by the Assembly, although the rules made this an infrequent occurrence. ${ }^{43}$

${ }^{40}$ MacDowell $(1978,62)$ writes that "the Greek sykophantes is a vague disparaging word for an unjustified accuser. Its origin is unknown, though many guesses have been made." Bonner $(1969,66)$ writes that "it is plain that hush money exacted from accused persons constitutes the mainstay of the large number of sycophants that infested Athens."

${ }^{41}$ For example, claimants to property confiscated by the state were required to post one-fifth the estate's value. See Bonner (1969, 49), MacDowell $(1978,239)$.

${ }^{42}$ This is consonant with the value ascribed to maritime activity and the sophistication of maritime courts (see the discussion in this paper's next section), as is the fact that the fine for failing to obtain one-fifth of the dikastai votes was more severe in maritime courts than in other courts. See Cohen $(1973,84)$.

${ }^{43}$ The Assembly heard accusations only once per year, and the penalty could be applied only to three citizens and three foreign residents annually. The penalty was a fine set by a court in a separate hearing 
The problem, of course, was that if the Athenians pursued sycophants too aggressively, they risked discouraging the legitimate voluntary prosecutions on which their system depended. It is not surprising, then, that, as MacDowell $(1978,66)$ writes, "the Athenians had great difficulty in suppressing sycophants.” Bonner $(1969,65)$ adds, “There are abundant indications in literature that sycophants were both numerous and formidable." This reflects the basic nature of the expertiserelated tradeoff: Athens could have done more to reduce the number of sycophants, but only by weakening the incentive for individuals to invest in public prosecution-related expertise (including private information about wrongdoing) that would enable them to bring forward socially beneficial cases. In the context of our model, the set of policies designed to encourage prosecutions while discouraging sycophancy represents a set of actions designed to make beneficial tradeoffs between $\delta$ and $\mu$ - the objective was to reduce $\mu$ by encouraging individuals to obtain and reveal information about actual offenses, while minimizing the increase in $\delta$ that inevitably resulted when individuals (sycophants in particular) faced incentives to prosecute cases that were personally profitable, even if the accused parties were innocent.

\section{MAKING USE OF LOW-COST EXPERTISE}

\section{A. Adjudication by Knowledgeable Participants: Maritime Courts}

In some circumstances, expertise will be very valuable (i.e., $\mu_{\mathrm{L}}$ is high relative to $\mu_{\mathrm{H}}$ ) and, at the same time, the incentives of experts will be relatively well aligned with those of the general public (i.e., $\delta$ is relatively small). In such cases, the decision to employ experts is straightforward. For the Athenians, the most important example of this involved maritime law.

(MacDowell 1978, 65). 
To begin with, it is important to note that commercial law in ancient Athens was strictly divided between law of landed transactions, astikoi nomoi, and law of the sea, emporikoi nomoi. ${ }^{44}$ The former, consistent with the general Athenian approach, was relatively simple - landed transactions were considered consummated only at the moment of exchange, so that any promises or claims made prior to exchange provided no grounds for complaint. ${ }^{45}$ In a famous case, a man named Epikrates purchased a perfume business, only to discover it was heavily burdened with debts that had not been disclosed to him. Although he bemoaned the injustice, he admitted that despite extensive search he had been unable to find a single law, precedent, or administrative procedure outlawing the treatment he had received. ${ }^{46}$

Maritime law was entirely different. Transportation by land was primitive and slow, valuable cargo traveled by sea, and the most valuable transactions were thus sea-borne. Athens was, first and foremost, a sea power - it was the great maritime power in Greece, even after its defeat in the

\footnotetext{
${ }^{44}$ Cohen $(2005,290-1)$ writes that "All commercial activity is 'sharply separated,' conceptually and legally, into kapeleia, landed retail trade, and emporia, exchange by sea - a division recognized juridically by the explicit separation of 'commercial maritime' laws (emporikoi nomoi) from those of the landed community (astikoi omoi)."

${ }^{45}$ Cohen $(2005,296)$ writes that "in the overwhelming majority of sales, there would be no 'agreement' prior to the simultaneous exchange of cash for goods and hence no basis for dispute actionable at law." It is possible that the sale of defective products may have been voided, but the record is somewhat ambiguous (Pringsheim 1950, 476). It is also likely that the seller was required to guarantee that he was the actual owner of the object being sold - a notion termed bebaioun (Harris 2006, 149) - although as the discussion of Epikrates in the text reveals, the definition of ownership was not always precise. Of course, landed transactions were likely to have been simple in part because the law was not sophisticated. But the fact that sophisticated maritime law supported sophisticated transactions (see what follows) suggests a more sophisticated law for landed transactions could have been supported had the net gains been sufficiently large.

${ }^{46}$ See Cohen $(2005,296)$. The one nod to sophistication in commercial markets was with respect to credit - most land was encumbered with mortgages (often more than one mortgage on a given plot of land). All such arrangements were enforceable in courts. Indeed, they flowed in a straightforward fashion from the underlying assumption that "whatever one party has agreed on with another" defines the transaction (to use Demosthenes' phrase) as long as the transaction has been consummated. (Quoted in Cohen 2005, 296).
} 
Peloponnesian War. ${ }^{47}$ Athens imported by sea the majority of grain consumed by its population (hundreds of ship loads per year), trading silver, wine, and olive oil (among other things) in return. Regular trade routes carried Athenian sailors to the Black Sea, Sicily, Lybia, and other distant places.

Sea trade did not allow the simple "simultaneous exchange" transactions that characterized landed dealings. Ships were extremely expensive to equip, cargo was usually very valuable, trips were of extended (and often unpredictable) duration, and many ships sank at sea. A system of maritime loans developed, with the distinctive characteristics of requiring repayment only upon successful completion of the journey, and of using the ship and/or cargo as security. Because multiple cargos belonging to multiple traders would be carried by a single ship, complicated sets of obligations resulted. This is illustrated by Cohen $(2005,298)$, drawing on a law court speech attributed to Demosthenes:

The vessel used for this transaction [traveling from Athens to Crimea] carried numerous merchants and agents pursuing their own separate undertakings: retainers of a certain Apollonides of Halikarnassos, a 'partner in the ship', were on board; a loan had been made to the ship operator secured by the vessel and by goods being transported to the Pontos; freight was being carried from Pantikapaion to Theodosia (in the Crimea) under arrangements unrelated to the loan.... So disparate were the transactions that in addition to crew members, eight other persons offered depositions concerning cargo transported from Mende to the Pontic, relating to other goods on board when the vessel was sailing along the Crimean coastline, and mentioning various financial arrangements covering diverse freight. The preserved contract clearly anticipates multiple cargos independently owned ... To keep track of these multitudinous obligations, Greek ship operators (naukleroi) are known to have carried numerous written documents.

MacDowell $(1978,233)$ states that such obligations

${ }^{47}$ See Cohen $(1973,7)$, who writes, "Her naval stranglehold broken forever in the Great Harbor at Syracuse in 413, Athens nonetheless maintained through most of the $4^{\text {th }}$ century a fleet seldom paralleled by any and excelled by none. Of all peoples she depended most on imported foodstuffs." In 340, Philip of Macedon seized between 180 and 230 grain ships bound for Athens in a single battle (Cohen 2005, 297). 
were often so complicated that a written statement of them was really necessary. A loan could be secured on a ship, or on the slaves who formed its crew, or on the cargo, or on some part of the cargo; the borrower could be required to purchase certain kinds of goods in a certain port.

When sophisticated contracts are disputed, effective adjudication requires that adjudicators have an understanding sufficient to assess the extent to which each party is at fault. A system based on non-expert adjudicators will invariably make many more mistakes - in the context of the model, $\mu_{\mathrm{L}}$ will greatly exceed $\mu_{\mathrm{H}}$. And, given the importance of maritime trade to the Athenian economy, frequent mistakes in the enforcement of maritime contracts would have imposed substantial costs on the general citizenry.

The Athenian response was to establish a system that employed relatively well informed adjudicators. However, they did this not by altering Athens' fundamental institutions of adjudication, but by restricting the set of men who could participate within them. All disputes involving written contracts bearing on sea-borne trade either emanating from or traveling to Athens were adjudicated in maritime courts known as dikai emporikai, and the dikastai in the dikai emporikai were chosen by lot solely from among the commercially active Athenian merchants at Piraeus (Athens' principal port). ${ }^{48}$ This had several advantages. First, these men had been (or were) engaged in contracts similar to those being litigated, and so were knowledgeable about the general issues. Second, the men could expect to adjudicate in the same venue if they, themselves, became

\footnotetext{
${ }^{48}$ See Cohen $(1973,93)$. Consistent with the unusual expertise of maritime adjudicators, Cohen, an expert on Athens' commercial courts who generally refers to dikasteria as "juries," writes, "The word 'courts' seems to me the preferable rendering for dikai in the term dikai emporikai [maritime courts] because their procedural and jurisdictional attributes differ markedly from other forms of legal action" $(2005,300)$. The dikai emporikai had the additional distinctive features of operating only in the winter months, when weather reduced sea-borne trade (Bonner 1969, 47), conducting litigation on an accelerated schedule, and punishing false accusations with unusual severity (Cohen 1973).
} 
involved in disputes, providing the incentive to become sufficiently informed about the particulars of the case so that no damaging precedents were established (and to protect themselves from sharp practices). Third, because the community of Piraeus was not overly large, the dikastai on the dikai emporikai would be likely to be familiar with the litigants, and thus able to tell honest men from rogues.

To understand why the Athenians ran their maritime courts so differently from their other courts - specifically, why they allowed only "experts" to serve as adjudicators of maritime contracts - it is important recognize not only that $\mu_{\mathrm{L}}$ was high and $\mu_{\mathrm{H}}$ low (so that the benefit of using experts was high), but that $\delta$ (the likelihood that an expert's preferences would diverge substantially from those of the representative citizen) was low. Said differently, when it came to maritime courts, the interests of the median citizen and median merchant were reasonably well aligned. All Athenians were enriched by maritime trade - merchants especially, of course - and thus stood to benefit from efficient and effective contract enforcement. Such enforcement was essential to the port's success, as is testified in the following speech by a litigant:

Do not ignore the fact that by resolving one dispute you are passing a law for the entire port of Athens. Many of the men who have chosen to engage in overseas trade are watching you to see how you will decide this case. If you think that written contracts and agreements between partners should be binding and you will not take the side of those who break them, those involved in lending will more readily make their assets available. As a result, the port will thrive, and you will benefit." ${ }^{\prime 4}$

In our model, expertise is harmful only to the extent that the expert seeks something that the

${ }^{49}$ Quoted in Harris $(2006,143)$. Consistently, and in marked contrast to other Athenian courts, where the general rule was "a foreigner has no rights" (Cohen 1973, 8), foreigners adjudicating in dikai emporikai stood on equal legal footing with Athenian citizens. Men of all nationalities involved in disputes over trade to or from Athens were required to litigate in the Athenian dikai emporikai, and would therefore not have been willing to trade in and out of Athens otherwise. 
representative citizen does not want. In the case of maritime courts, that was unlikely to have been the case. As a result, doing without expertise in maritime courts would have generated costs (reducing the value of Athens' port and trade) without producing offsetting benefits (since merchant and non-merchant citizens had similar incentives regarding optimal maritime contract enforcement).

\section{B. Adjudication by Constrained Parties: Use of Public Slaves}

For the performance of some tasks, it may be feasible to develop a set of experts who lack the ability (or strong incentives) to engage in rent seeking. If so, $\delta$ will be relatively small. An important example from Athens is the use of public slaves (i.e., slaves owned by the state). Athens relied on public slaves to play a variety of roles: secretary, clerk, prison attendant, executioner, scribe, accountant. Perhaps most famously, public order was kept by a force of about 300 "Scythian archers" (who may have been neither entirely Scythian nor entirely archers). ${ }^{50}$

Of greatest relevance to our analysis are the public slaves used to support market transactions, specifically by ensuring the validity of weights and measures and by verifying the acceptability of coins. Disputes about the characteristics of products for sale in the market (agora) were common; each market therefore kept its own set of weights and measures. ${ }^{51}$ Of course, to engender confidence, the measures had to be protected from tampering. Because tampering was difficult to detect, it was important that the measures be safeguarded when not in use, and because tampering could be profitable, it was important that the guardian be difficult to bribe. So Athenians assigned the task to public slaves. These slaves were stationed at various points around the market. If a

\footnotetext{
${ }^{50}$ See Hansen $(1999,124)$ and Baughman (2003). Scythian archers are portrayed in several of Aristophanes' plays, usually beating disorderly citizens.

${ }^{51}$ See Barzel (1982) on costly duplicative measurement.
} 
dispute arose - a buyer and seller disagreed over the weight or size of an item - a magistrate would be summoned; he would summon in turn one of the slaves, who would bring out the official measures and resolve the dispute. ${ }^{52}$ These slaves were not allowed to amass wealth, marry, or beget children. They answered to the revolving magistrates, who were audited upon leaving office and answered in turn to the Popular Assembly. The slaves had little incentive to do anything but guard the weights and measures carefully; thus, $\delta$ was small.

Public slaves also adjudicated disputes over the validity of coins, which were the principal medium of exchange. Athenian silver coins were relatively simple in design (the coins were known as "owls" because an owl was pictured on one side), and hence not difficult to counterfeit. In fact, counterfeit coins were acceptable as long as they contained the requisite quantity of silver. However, counterfeiters profited by diluting the silver with less precious medals. Therefore, stationed at each market was a public slave called the dokimastes ("tester"), who sat near where the bankers conducted their business. The dokimastes' task was to evaluate disputed coins. After the testing, genuine coins were returned to their owner while counterfeit coins were confiscated (cut in two and turned over to the temple priest). Anyone who refused to accept the coins approved by the dokimastes had all goods on display confiscated. If the dokimastes were found to have acted falsely, he received fifty lashes. ${ }^{53}$ This would have reduced the scope of moral hazard; thus, once again, in the context of the model, $\delta$ was small.

${ }^{52}$ See Harris $(2006,147-8)$ for a description. Harris quotes from a document of the time: "To keep the official weights and measures in permanent use, the law instructs a certain Diodorus, the son of Theophilus from the deme of Halieus to hand them over to three public slaves stationed in various places. These slaves are to make them available to any magistrates who request them."

${ }^{53}$ See Harris $(2006,148)$ and MacDowell $(1978,158)$ for more detail. 


\section{Adjudication by Incentive-Aligned Outsiders: Private Arbitration}

Rather than litigating, private disputants in Athens could (and often did) employ private arbitrators. ${ }^{54}$ Arbitration allowed disputes to be discussed informally and without time limit, rather than formally (through speeches) in a limited time period (circa 15 minutes per speech) as in a law court. The arbitrator could ask questions to clarify the nature of the dispute (dikastai simply listened) and suggest compromises (dikastai simply chose between alternate punishments).

The process began with disputants selecting a mutually acceptable candidate (or candidates) to act as arbitrator. They would also agree on the question to be addressed and the rules to be followed (whether this agreement was invariably written is unclear). If litigation had already commenced, the responsible magistrate was notified of the arbitration, and the suit was dropped. Upon the completion of arbitration, the arbitrator handed down a decision, which was legally binding. ${ }^{55}$

To the degree that disputants preferred arbitrators who were more expert in the law (and in reconciling disputing parties), private arbitrators (unlike dikastai) would have had the incentive to invest in expertise. At the same time, the possibility that the arbitrator would use his expertise to extract rents (bribes, for example) would have been muted by the fact that the choice of private arbitrators was voluntary - developing a reputation for dishonesty would presumably have damaged

\footnotetext{
${ }^{54}$ There was also a system of mandatory public arbitration established early in the fourth century BCE. All citizens aged fifty-nine were required to serve for a year as public arbitrators (diaitetes) - see Hansen $(1999,197)$. Public arbitration, in contrast to private arbitration, was not binding; however, disputants who chose to appeal a public arbitrator's decision could only present in the law courts the evidence, arguments, and witnesses that had been employed during public arbitration. For more detail, see, e.g., MacDowell (1978, 203-6) on private arbitration and (206-11) on public arbitration.

${ }^{55}$ MacDowell $(1978,209)$ writes, "In private arbitration both disputants agreed voluntarily to submit their dispute to an arbitrator selected by themselves, so it is reasonable that they were then required by law to accept the verdict as final, having the same validity as a jury's verdict."
} 
an arbitrator's business.

In short, private arbitration allowed Athenians to employ a semi-professional class of judges with limited ability to engage in rent seeking. ${ }^{56}$ In the context of our model, Athenian disputants (for a select set of cases) could benefit from expertise (by reducing the frequency of mistakes from $\mu_{\mathrm{L}}$ to $\mu_{\mathrm{H}}$ ) in a manner that was more than worth the cost. This worked because the mutually voluntary nature of the disputants' decision to enter arbitration, combined with reputation-based incentives for arbitrators, meant that $\delta$ was small.

\section{THE ABANDONED ALTERNATIVE: AN EXPERT COURT OF LAST RESORT}

What makes the "low-expertise" nature of Athenian legal institutions especially intriguing is that it resulted from an explicit institutional redesign, not from the persistence of outdated traditions. The Athenians were clearly aware of higher-expertise alternatives to their legal institutions. In fact, during the two centuries before the Classical period, the Athenians had relied heavily on what was, in effect, an independent high court of life-serving judges. The institution was known as the Areopagus, and its mandate had been, in Starr's (1990, 8-9) words, "Guardianship of the laws." ${ }^{, 57}$ The Areopagus had been the ultimate adjudicatory institution, and Starr writes that "As a standing body, its powers were probably preeminent" (page 5).

The Areopagus' membership consisted of all men who had served a one-year term as archon,

${ }^{56}$ This is suggested by Lofberg (1921).

${ }^{57}$ The name means "Hill of Ares," on which the Areopagus met. The precise size of the Areopagus is not known, but an average membership of about 150 is thought to be typical for the Classical period. See, e.g., Hansen $(1999,290)$ and MacDowell $(1978,27)$. 
or "chief magistrate;" in the Classical period, nine archons, chosen by lot, served concurrently. ${ }^{58}$ After undergoing an initial process of scrutiny, ex-archons remained on the Areopagus for life. Life service provided Areogpagites with an incentive (lacked by dikastes) to become expert in the law. And, of course, repeated exposure to litigation would have lowered the cost that Areopagites had to incur to obtain and maintain that expertise. As a result, the Areopagus was as close to an independent court of professional judges as ever existed in ancient Athens: Its membership could not easily be changed, and it decisions could not be challenged in dikasteria or before the Popular Assembly.

But adjudication by independent experts was precisely what Classical period Athens sought to avoid, and the responsibilities of the Areopagus were sharply curtailed in the fifth century. ${ }^{59}$ Most of its powers were divided among other political bodies (e.g., the Popular Assembly, the dikasteria) and it was limited to a single function: hearing cases involving the homicide of an Athenian citizen. ${ }^{60}$

Thus, the Athenian legal system's extraordinary emphasis on adjudication by non-experts did not result from ignorance, neglect, or the survival of obsolete institutions. Rather, it emerged as a

${ }^{58}$ Archons were assigned primary administrative responsibility for religious, administrative, and military affairs; see MacDowell (1978, 24). Archon means "leader" or "ruler," and first emerged as an office early in the Archaic period when Athens - like many city-states - ended its practice of having a king (the erstwhile kingly powers appear have been divided among several archons, each chosen from one of the thennoble families of Athens).

${ }^{59}$ In 507, Kleisthenes transferred to the Assembly responsibility for political trials, while in 462 , reforms generally attributed to Ephialtes stripped the Areopagus of most of its remaining powers. See Starr $(1990,25)$.

${ }^{60}$ This was still an important responsibility - the homicide of a citizen was considered a much more serious offense than the homicide of a foreign resident or slave (Hansen 1999, 99). On Athenian homicide trials, and in particular the incentive effects of the institutional design, see McCannon (2010a). 
purposeful design. Athens made a conscious effort to discourage legal expertise - to the extent of dis-empowering its most expert and professional adjudicatory body.

\section{CONCLUSION}

The ancient Athenians established a unique set of legal institutions. These institutions supported sophisticated contracts, motivated public prosecutions, and generally deterred wrongdoing. However, they looked very little like modern institutions. To understand why the Athenians developed the system they did, we have modeled a tradeoff inherent in the use of legal expertise: Relying on experts can provide a mechanism for more accurate assessment of information (which helps to support the implementation of sophisticated rules and contracts), but it also allows policy to be shifted in socially harmful directions. Modern societies have generally chosen to accept the costs of professional legal expertise in return for the benefits. The Athenians decided differently.

What can we learn from the Athenian experience? One of the most notable features of the Athenian system is how its parts complemented one another. If judges were to be randomly chosen citizens, professional lawyers could not be allowed - professionals could too easily mislead untrained adjudicators. But if professional lawyers were not allowed, professional public prosecutors could not be allowed either - defendants would otherwise be at a marked disadvantage. And if professional public prosecutors were not allowed, the state would have to rely on volunteers to prosecute public offenses. But if voluntary prosecutors were to be motivated, a system of rewards would have to be established. And this all required, in addition, that Classical Athens, so famous for its copious written poetry, drama, philosophy, and history, not rely entirely (or even primarily) on written law - Christ $(1998,24)$ writes, "Vague laws left interpretation to the discretion of popular 
juries and thus ensured that a democratic body would have the last word on enforcement. If the laws were more specific that might make them more complicated and give expert litigants an unfair advantage."

A similar linking of complementary parts - though very different types of parts - can be seen in modern legal systems: Professional litigators must be overseen by professional judges, and so forth. This highlights an essential feature of well functioning legal systems, whether modern or ancient: The component parts must be a matching set. Thus, when scholars or politicians contemplate reforms for societies with ineffective legal institutions, it is important that they recognize that simply taking an institution that works well in one place and transplanting it to another may produce disastrous results.

Most empirical studies of the benefits of legal institutions (e.g., Feld and Voigt 2003; La Porta et al. 2004) measure ceteris paribus effects. For example, La Porta et al. find that judicial independence is associated with a host of benefits (e.g., greater economic and political liberties, better property rights protections). While their results demonstrate the importance of good institutions, it does not follow that a reform that increases the independence of judges in a given country will be beneficial in the absence of other institutional changes. For example, had a professional and independent judiciary been allowed in Athens while professional litigators remained banned, inordinate influence would have been concentrated in a few knowledgeable hands (which is precisely what the Athenians feared). The point may seem obvious, but is worth stressing: Institutions are a bundle, and must be understood that way. 


\section{Bibliography}

Aghion, Philippe, Alberto Alesina, and Francesco Trebbi. 2004. "Endogenous Political Institutions." Quarterly Journal of Economics 119:565-611.

Bandyopadhyay, Siddhartha, and Bryan C. McCannon. 2010. "The Effect of the Election of Prosecutors on Criminal Trials." http://papers.ssrn.com/sol3/papers.cfm?abstract_id=1641345.

Barzel, Yoram. 1982. "Measurement Costs and the Organization of Markets." Journal of Law and Economics 25:27-48.

Baughman, Elizabeth. 2003. "The Scythian Archers: Policing Athens." In C. Blackwell, editor, Dèmos: Classical A Athenian Democracy. Published by The Stoa: A Consortium for Electronic Publication in the Humanities, A. Mahoney and R. Scaife, editors.

http://www.stoa.org/projects/demos/home.

Bergara, Mario, Barak Richman, and Pablo T. Spiller. 2003. "Modeling Supreme Court Strategic Decision Making: The Congressional Constraint." Legislative Studies Quarterly 28:247-280.

Blundell, Sue. 1995. Women in Ancient Greece. Cambridge: Harvard University Press.

Bonner, Robert J. 1969. Lawyers and Litigants in Ancient Athens. New York: Benjamin Blom.

Carey, C. 1998. “The Shape of Athenian Laws.” Classics Quarterly 48:93-109.

Christ, Matthew R. 1998. The Litigious Athenian. Baltimore, MD: Johns Hopkins University Press.

Cohen, Edward E. 1973. Ancient Athenian Maritime Courts. Princeton: Princeton University Press.

Cohen, Edward E. 2005. "Commercial Law." Chapter 15 in Michael Gagarin and David Cohen, editors, The Cambridge Companion to Ancient Law Athens. Cambridge: Cambridge University Press.

Dahl, Robert A. 1957. "Decision-making in a Democracy: The Supreme Court as a National Policy-maker." Journal of Public Law 6:279-295.

Dahl, Robert A. 1989. Democracy and its Critics. New Haven: Yale University Press.

Epstein, Lee, Daniel E. Ho, Gary King, and Jeffrey A. Segal. 2005. “The Supreme Court During Crisis: How War Affects Only Non-War Cases." New York University Law Review 80:1-116. 
Epstein, Lee, Jack Knight, and Andrew D. Martin. 2001. "The Supreme Court as Strategic National Policymaker.” Emory Law Journal 50:583-611.

Eskridge, William. 1991. "Reneging on History: Playing the Court/Congress/President Civil Rights Game.” California Law Review 79:613-684.

Feld, Lars P., and Stefan Voigt. 2003. "Economic Growth and Judicial Independence: Cross-Country Evidence Using a New Set of Indicators." European Journal of Political Economy 19:497-527.

Ferejohn, John, and Barry Weingast. 1992. "Limitation of Statutes: Strategic Statutory Interpretation." Georgetown Law Journal 80:565-82.

Fleck, Robert K., and F. Andrew Hanssen. 2006. "The Origins of Democracy: A Model with Application to Ancient Greece.” Journal of Law and Economics 49:115-146.

Fleck, Robert K., and F. Andrew Hanssen. 2009. “'Rulers Ruled by Women': An Economic Analysis of the Rise and Fall of Women's Rights in Ancient Sparta." Economics of Governance 10:221-245.

Fleck, Robert K., and F. Andrew Hanssen. 2010. "Repeated Adjustment of Delegated Powers and the History of Eminent Domain." International Review of Law and Economics 30:99-112.

Fleck, Robert K., and F. Andrew Hanssen. 2011. "How Tyranny Paved the Way to Wealth and Democracy: The Democratic Transition in Ancient Greece." Working paper, Montana State University and Clemson University.

Fleck, Robert K., and F. Andrew Hanssen. Forthcoming. "Judicial Review as a Constraint on Tyranny of the Majority." Journal of Law, Economics, and Organization.

Friedman, Barry. 2002. "The Birth of an Academic Obsession: The History of the Countermajoritarian Difficulty, Part Five." Yale Law Journal 112:153-259.

Frier, Bruce W., and Dennis P. Kehoe. 2007. "Law and Economic Institutions." Chapter 5 in The Cambridge Economic History of the Greco-Roman World, W. Scheidel, I. Morris, and R. Saller, editors, pp. 113-143. Cambridge: Cambridge University Press.

Glaeser, Edward, Simon Johnson, and Andrei Shleifer. 2001. "Coase Versus the Coasians." Quarterly Journal of Economics 116:853-899.

Glaeser, Edward L., Daniel P. Kessler, and Anne Morrison Piehl. 2000. "What Do Prosecutors Maximize? An Analysis of the Federalization of Drug Crimes." American Law and Economics Review 2:259-290. 
Hansen, Mogens H. 1999. The Athenian Democracy in the Age of Demosthenes. Norman, OK: University of Oklahoma Press.

Hanssen, F. Andrew. 1999. "The Effect of Judicial Institutions on Uncertainty and the Rate of Litigation: The Election Versus Appointment of State Judges." Journal of Legal Studies 28:205-32.

Hanssen, F. Andrew. 2000. "Independent Courts and Administrative Agencies: An Empirical Analysis of the States.” Journal of Law, Economics, and Organization 16:534-71.

Hanssen, F. Andrew. 2004a. "Is there a Politically Optimal Level of Judicial Independence?" American Economic Review 94:712-729.

Hanssen, F. Andrew. 2004b. "Learning about Judicial Independence: Institutional Change in the State Courts." Journal of Legal Studies 33:431-473.

Harris, Edward M. 2006. Democracy and the Rule of Law in Classical Athens. Cambridge: Cambridge University Press.

Karachalios, Foivos. 2011. "The Politics of Judgment: Dispute Resolution and State Formation in Archaic Greece." Working paper, Stanford University.

Landes, William M., and Richard A. Posner. 1975. "The Independent Judiciary as an Interest Group Perspective." Journal of Law and Economics 18:875-02.

Lanni, Adriaan. 2005. "Relevance in Athenian Courts." Chapter 6 in Michael Gagarin and David Cohen, editors, The Cambridge Companion to Ancient Law Athens. Cambridge: Cambridge University Press.

La Porta, Rafael, Florencio Lopez-de-Silanes, Cristian Pop-Eleches, and Andre Shleifer. 2004. "Judicial Checks and Balances." Journal of Political Economy 112:445-470.

Lofberg, J.O. 1921. "Trial by Jury in Athens and America.” The Classical Journal 17:3-15.

MacDowell, Douglas M. 1978. The Law in Classical Athens. Ithaca: Cornell University Press.

Maskin, Eric and Jean Tirole. 2004. "The Politician and the Judge: Accountability in Government", American Economic Review 94:1034-54.

Matsusaka, John G. 1992. "Economics of Direct Legislation.” Quarterly Journal of Economics 107:541-571.

Matsusaka, John G. 2005. "Direct Democracy Works." Journal of Economic Perspectives 19:185-206. 
McCannon, Bryan C. 2010a. "Homicide Trials in Classical Athens." International Review of Law and Economics 30:46-51.

McCannon, Bryan C. 2010b. "The Median Juror and the Trial of Socrates." European Journal of Political Economy 26:533-540.

McCannon, Bryan C. 2011. "Jury Size in Classical Athens: An Application of the Condorcet Jury Theorem." Kyklos 64:106-121.

Millet, Paul. 1991. Lending and Borrowing in Ancient Athens. Cambridge: Cambridge University Press.

Morris, Ian. 2010. Why the West Rules - For Now. New York: Farrar, Straus, and Giroux.

Ober, Josiah. 2006a. "Learning from Athens: Democracy by Design.” Boston Review 31:13-17.

Ober, Josiah. 2006b. "From Epistemic Diversity to Common Knowledge: Rational Rituals and Cooperation in Democratic Athens." Episteme 3:214-233.

Ober, Josiah. 2008. Democracy and Knowledge. Princeton: Princeton University Press.

Ober, Josiah. 2010. "Wealthy Hellas." Transactions of the American Philological Association 140:241-286.

Ostwald, Martin. 1986. From Popular Sovereignty to the Sovereignty of Law: Law, Society, and Politics in Fifth-Century Athens. Berkeley: University of Californian Press

Pomeroy, Sarah B. 1975. Goddesses, Whores, Wives, and Slaves: Women in Classical Antiquity. New York: Shocken Books.

Pomeroy, Sarah B. 2002. Spartan Women. New York: Oxford University Press.

Pringsheim, Fritz. 1950. The Greek Law of Sale. Weimar: Hermann Bohlaus Nachfolger.

Qian, Yingyi, and Barry R. Weingast. 1997. "Federalism as a Commitment to Preserving Market Incentives." Journal of Economic Perspectives 11:83-92.

Rasmusen, Eric, Manu Raghav, Mark Ramseyer. 2011. "Convictions versus Conviction Rates: The Prosecutor's Choice" American Law and Economics Review 11:47-78.

Sealey, Raphael. 1987. The Athenian Republic: Democracy or the Rule of Law? London: Pennsylvania State University Press.

Spiller, Pablo T., and Rafael Gely. 1992. "Congressional Control or Judicial Independence: 
The Determinants of U.S. Supreme Court Labor-Relations Decisions, 1949-1988.” RAND Journal of Economics 23:463-492.

Starr, Chester C. 1990. The Birth of Athenian Democracy: The Assembly in the Fifth Century B.C. New York: Oxford Press.

Stuntz, William J. 2001. "The Pathological Politics of Criminal Law." Michigan Law Review 100:505-600.

Todd, Stephen C. 2005. "Law and Oratory at Athens." Chapter 5 in Michael Gagarin and David Cohen, editors, The Cambridge Companion to Ancient Law Athens. Cambridge: Cambridge University Press.

Todd, Stephen, and Paul Millet. 1990. "Law, Society and Athens." Chapter 1 in Paul Cartledge, Paul Millet, and Stephen Todd, editors, Nomos: Essays in Athenian Law, Politics and Society. Cambridge: Cambridge University Press.

Todd, Stephen. 1990. "The Purpose of Evidence in Ancient Athens." Chapter 2 in Paul Cartledge, Paul Millet, and Stephen Todd, editors, Nomos: Essays in Athenian Law, Politics and Society. Cambridge: Cambridge University Press.

Weingast, Barry R. 1995. "The Economic Role of Political Institutions: Market-Preserving Federalism and Economic Development." Journal of Law, Economics, and Organization 11:1-31. 